Review

\title{
Forest Accountancy Data Networks-A European Approach of Empirical Research, Its Achievements, and Potentials in Regard to Sustainable Multiple Use Forestry
}

\author{
Philipp Toscani * (i) and Walter Sekot \\ Institute for Agricultural and Forestry Economics, University of Natural Resources and Life Sciences, Vienna, \\ 1180 Vienna, Austria; walter.sekot@boku.ac.at \\ * Correspondence: philipp.toscani@boku.ac.at; Tel.: +43-1-47654-73316
}

Received: 1 March 2018; Accepted: 17 April 2018; Published: 19 April 2018

check for updates

\begin{abstract}
A Forest Accountancy Data Network represents an intermediate approach of empirical economic research between surveys based on questionnaires on the one hand and case studies on the other, with time as a third dimension. Over the past decades, the few institutions operating such networks have accumulated a bulk of experience with this methodology and the possibilities for its adaptation to upcoming requirements. By summarizing and evaluating the potential of this methodology, we provide an up-to-date reference for designing empirical studies in forest economics at the enterprise level. Aspects of sustainability as well as the economics of multiple use forestry are specifically addressed. Forestry-specific extensions to existing agricultural networks could be a cost saving approach for investigating such crucial questions like the role of forestry for regional development and for the livelihood of farms. The study is based on an extended literature research which has been complemented by expert interviews.
\end{abstract}

Keywords: forest accountancy data network; cost accountancy network; farm forestry; multiple use forestry; profitability; sustainability; DACH-Initiative; small-scale forestry

\section{Introduction}

Forests and other wooded land cover approximately 43\% (182 million hectares) of the EU-28 land area, thereby even exceeding the land used for agricultural purposes [1]. Within the countries of the European Union the share of forest land differs significantly between $1.1 \%$ in Malta and $73.1 \%$ in Finland. A look at the owner structure of European forests shows similar heterogeneity. The share of public-owned forests amounts to 3.0\% in Portugal but $87.9 \%$ in Bulgaria. On average, $60.3 \%$ of the EU-28 forests are owned privately. According to the definition of the forest resource assessment (FRA) 2015, private-owned forests are all types of ownership that are not public such as individuals, communities, corporations, religious and other institutions [2]. The size of private forest holdings ranges from less than 1 ha up to several thousand hectares. In the European Union there are more than 12 million private forest owners [3] with the better part owning forests with a size of less than 1 ha [4]. Larger units are often operated as forest enterprises striving for achieving a sustainable income from managing the forest land. The owner structure of small forests is very heterogeneous and may be grouped into (i) traditional forest owners; (ii) transitional type; and (iii) new forest owners [5]. Small forest ownership especially belonging to traditional forest owners is often associated with terms like farm forestry, family forestry, or small-scale forestry [6]. Farm forestry can play a significant role for the livelihood of farms, especially in mountainous regions [7]. Whereas in many countries measuring the profitability and monitoring the sustainability of forestry is possible for state forest 
organizations, there is a severe lack of knowledge about the socio-economic situation of small and/or privately-managed forest enterprises.

Accountancy networks are very powerful research tools for respective economic investigations. They represent a methodological alternative to surveys on the one hand and case studies on the other as regards the dimensions, number of units of investigation and volume of items collected for each unit. This intermediate characteristic as a research approach is reflected by the special quality of the information collected in terms of validity, reliability and accuracy. They are especially suited for monitoring purposes. Typically, the units of investigation provide their accounting data annually for a longer period of time. In agriculture, accountancy networks are even indispensable for economic monitoring. All member states of the European Union are legally obliged to operate a Farm Accountancy Data Network (FADN) [8], thus safeguarding a consistent empirical basis for the Common Agricultural Policy.

The low level of competition among producers is a most favorable frame condition for similar approaches of economic monitoring also in European forestry. During the last decades, a small number of Forest Accountancy Data Networks (FANs) have been implemented independently [6]. To obtain an overview and assess the potential for harmonization, the European Union launched the Concerted Action MOSEFA 'Monitoring the Socio-economic Situation of European Farm Forestry' in 1997 [9]. One of the major outcomes of the project were guidelines for establishing farm forestry accountancy networks [3]. These guidelines are based on the experiences of European countries operating FANs. A FAN is a long-term monitoring system in which socio-economic data of a sample of forest enterprises is systematically, mostly annually collected. In some cases separate networks are operated for either different sizes of forest land (e.g., Austria has two FANs, one for smaller holdings below 500 ha forest land and one for larger holdings with above 500 ha) and/or different types of property (e.g., Germany collects data from state, communal and private forest enterprises) [10]. Results are often published annually and contain information about the whole sample as well as subsets (e.g., alpine versus non-alpine regions) [3]. The findings try to fulfill the needs of different stakeholders at the same time. Typical target groups [11] are the individual forest owners, policy, science and education professionals. Selected results are usually part of national reports and underlie sector statistics. The countries of the DACH-region (Germany (D), Austria (A) and Switzerland (CH)), Norway and the Netherlands share a long tradition in operating and refining FANs $[3,12]$ at the national level as well as for some federal states. As those networks evolved independently, any comparison of results requires prudence. Profound knowledge and a harmonization of key figures are indispensable for sound international comparisons [10,12].

The nature of FANs being set up as long-term monitoring systems gives them a special characteristic. On the one hand interpretation must consider typical effects like panel effects or non-representativeness of sampled data [13]. On the other hand collected information is not only limited to current needs and so some 'treasures' [14] might be found in the FAN data. FANs were originally designed with a strong focus on timber production. During the last half century of their existence, the need for a holistic documentation of multiple use forest management arose. Hence the concepts were enhanced to fulfill these requirements to at least some point. Nevertheless, FANs are a concept of empirical research from a managerial economics point of view. In contrast to conventional sector statistics that document the income generated by the industry and welfare economics which address benefits derived from forests, FANs represent the economics of individual forest enterprises [15]. As part of the special issue 'At the Frontiers of Knowledge in Forest Economics' that offers a compilation of articles that aim to delineate the current state-of-knowledge on forest economics, this paper deals with a specific method for monitoring the profitability and efficiency of forest enterprises, 'forest accountancy data networks', which is in fact a core issue in European forest economics. The concept of the manuscript is to summarize the state of the art in applying this approach, reflect current achievements and explore the potentials for further developments with special consideration of how this approach is suitable for the monitoring of sustainable outcomes of 
forestry. The research is based on a systematic literature review and expert interviews about FANs in Europe with a focus on the DACH-region. An additional unique feature of this paper is, that it provides an overview of published as well as selected gray literature in this field of research.

\section{Materials and Methods}

We followed the PRISMA guidelines (Preferred Reporting Items for Systematic Reviews and Meta-Analyses) [16] for systematic literature reviews to identify relevant manuscripts dealing with the method FAN. The electronic databases Scopus, Web of Science, and ScienceDirect were searched on 28 December 2017 using combinations of the keywords 'forest accountancy data network', 'cost accountancy data network', their German translations, and the locally used acronyms for the FAN in the DACH-region. The search string used for Scopus was '((accountancy AND data AND network) OR (cost AND accountancy AND network) OR (Testbetriebsnetz) OR (TBN)) AND (forest OR forestry OR forst) OR (TBN-Forst) OR (ForstBAR)'. The systematic review led to 36 publications. Based on their abstracts, 19 publications containing relevant information about FAN were selected. The reference lists of these publications were screened to identify additional sources of information. Using this approach 43 additional sources were identified. After removing duplicate items, the abstracts of the remaining publications were checked. Publications including information about the concepts, results or comparisons of FANs were included in the presented results. The identified literature as well as the steps of exclusion is documented in the supplementary Table. The review process led to a total of 46 publications, 19 stemming from the primary search, 27 from the secondary. Table 1 gives additional descriptive information about the selected publications.

Table 1. Descriptive information about the 46 full-text articles assessed for eligibility for this study.

\begin{tabular}{ccc}
\hline Item & Characteristics & Number \\
\hline \multirow{2}{*}{ Search results } & Primary (electronic database) & 19 \\
& Secondary (identified through primary results) & 27 \\
\hline \multirow{2}{*}{ Publication language } & English & 22 \\
& German & 24 \\
\hline \multirow{2}{*}{ Type of publication } & Reviewed article & 13 \\
& Report & 12 \\
& Proceedings & 10 \\
& Article & 7 \\
Additional information & Book (chapter) & 4 \\
\hline \multirow{2}{*}{ Aumber of different authors } & 42 \\
& Publication years & $1967-2018$ \\
\hline
\end{tabular}

To obtain an overview of the current status of FANs operated in European countries, written expert interviews were carried out. Based on the results from MOSEFA [17], the 13 researchers or the respective research organizations of the reporting countries were contacted via E-mail on 17 January 2018 and asked for the development of FANs in their countries since the MOSEFA report, the current state, and links to further information about the network. The response rate was almost $85 \%$. For Ireland and Sweden no responding contact and information could be found.

\section{Results}

The systematic literature review led to a total of 46 eligible articles from which 26 were finally included in the presented results. The identification and screening process is illustrated as a flow diagram (see Figure 1), according to the PRISMA guidelines [16]. 


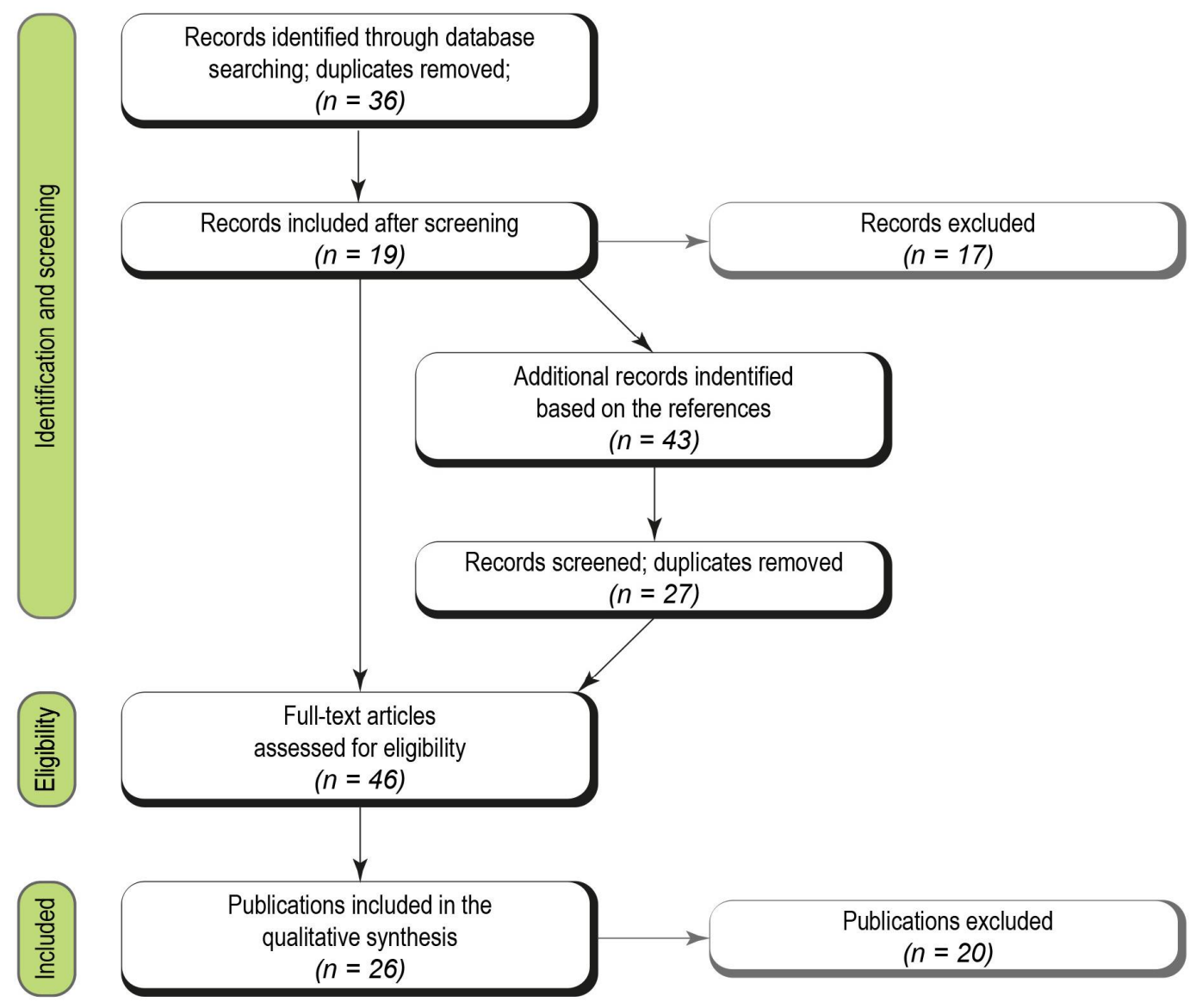

Figure 1. Flow diagram of the literature search process, showing the number of included and excluded studies at each stage according to the PRISMA guidelines [16].

The results are presented as a synthesis of the different publications according to six major topics: (i) The concept of FANs; (ii) status of European FANs; (iii) units of survey and reporting; (iv) general concepts of accounting and economic ratios for timber production; (v) sustainability; and (vi) multifunctionality, diversification and total economy of farm.

\subsection{Concept of FAN}

A FAN is a form of empirical economic research infrastructure consisting mainly of a sample of enterprises regularly providing accounting data and a central database where the information is stored [18]. Various groups with different informational needs benefit from FANs. Potential users of the results are forest owners, forest owners' associations, forestry advisory and extension organizations, policy-makers and governments, banks and other financial institutions as well as forestry research and education professionals [6]. Within the concept of any specific FAN the respective target groups and their information requirements have to be specified. The focus can be set from narrow (e.g., the Austrian FAN for small-scale forestry is primarily run for political purposes) to broad (e.g., the German FAN Westphalia-Lippe comprising data from private and municipal forest enterprises which are integrated in the nationwide FAN as well as for consultancy services [19]). Data for FANs is mostly collected annually either in the field by specialized staff or it is reported by the enterprises themselves [3]. The latter is the common way in Germany and Switzerland. In this system, participating enterprises submit their report up to the due date and after data checking through specialists a financial reward is paid. According to several confidential personal communications, monetary incentives provided to the individual forest owner vary in the range from $€ 30$ to $€ 600$ across the DACH-region. In contrast for both Austrian FANs, data is collected by specialized staff in the field. The enterprises taking part in the 
Austrian FAN for larger holdings ( $>500$ ha) even contribute to financing the cost of data collection in the range of $€ 50$ to $€ 250$. Most networks are operated in cooperation with public authorities, research institutions and forest owners' associations. Although FAN results are used to answer forestry political questions, operating an FAN is in no case specifically requested by law. At least in Germany the FAN serves as the means to fulfill the legal obligation to report on the economic situation and development of the forest industry [20]. Regional initiatives for fostering an economic understanding of farmers by means of exercises in interfirm comparison as well as comparative business analyses by consultants share at least some characteristics of an FAN [21,22]. Even though FANs are often planned as long-term socio-economic monitoring systems, in some cases they are run just for a defined time period (e.g., Austrian FAN for small wood lots [6]) or may be shut down due to a fade-out of funding (e.g., FAN for jointly-owned forests in Western Austria) [13].

\subsection{Status of European FANs}

The wish to compare the cost-revenue structure in forestry of European countries goes back a long time. More than five decades ago a group of forest economists designed the report 'Cost Studies in European Forestry' [23]. In this report, basic information about forestry, forest industries as well as costs and revenues in forestry is documented and evaluated by the eight participating countries of Austria, Denmark, Finland, Germany, Norway, Sweden, Switzerland and the United Kingdom. An acknowledged disadvantage of this study was the fact that for most participating countries the presented results referred to state forest organizations only, which account for a limited share of industry. Three decades later the project for 'Monitoring the Socio-Economic Situation of European Farm Forestry' (MOSEFA [17]) tried to overcome this problem by focusing on private forest owners. A total of 17 research facilities from 14 European countries took part in the MOSEFA project. The main outcomes of the project were making the existing experiences and expertise on FAN available and the provision of guidelines [3] for collecting socio-economic data on farm-forestry. The development since the MOSEFA project and the current status about active FANs in Europe was evaluated based on expert interviews. Seven European countries operating FANs could be identified: Austria, Denmark, Finland, Germany, the Netherlands, Norway, and Switzerland. Public availability of results of these FANs is heterogeneous, varying between annual reports on the situation of forestry (e.g., Germany [24], Switzerland [25]), a basis for official statistics (e.g., Austria [26]) and no publication (e.g., Finland). Apart from Hungary and some regional initiatives in Germany, no European country has implemented an FAN during the last twenty years. However, the Hungarian FAN was already shut down. In Italy information from a very small sample was collected around 2013 to test a methodology for research purposes but this did not result in establishing an FAN. When combining the information of operated FANs and forest land coverage in Europe, it is obvious that high forest density does not necessarily correlate with the existence of an FAN and vice versa (see Figure 2). 


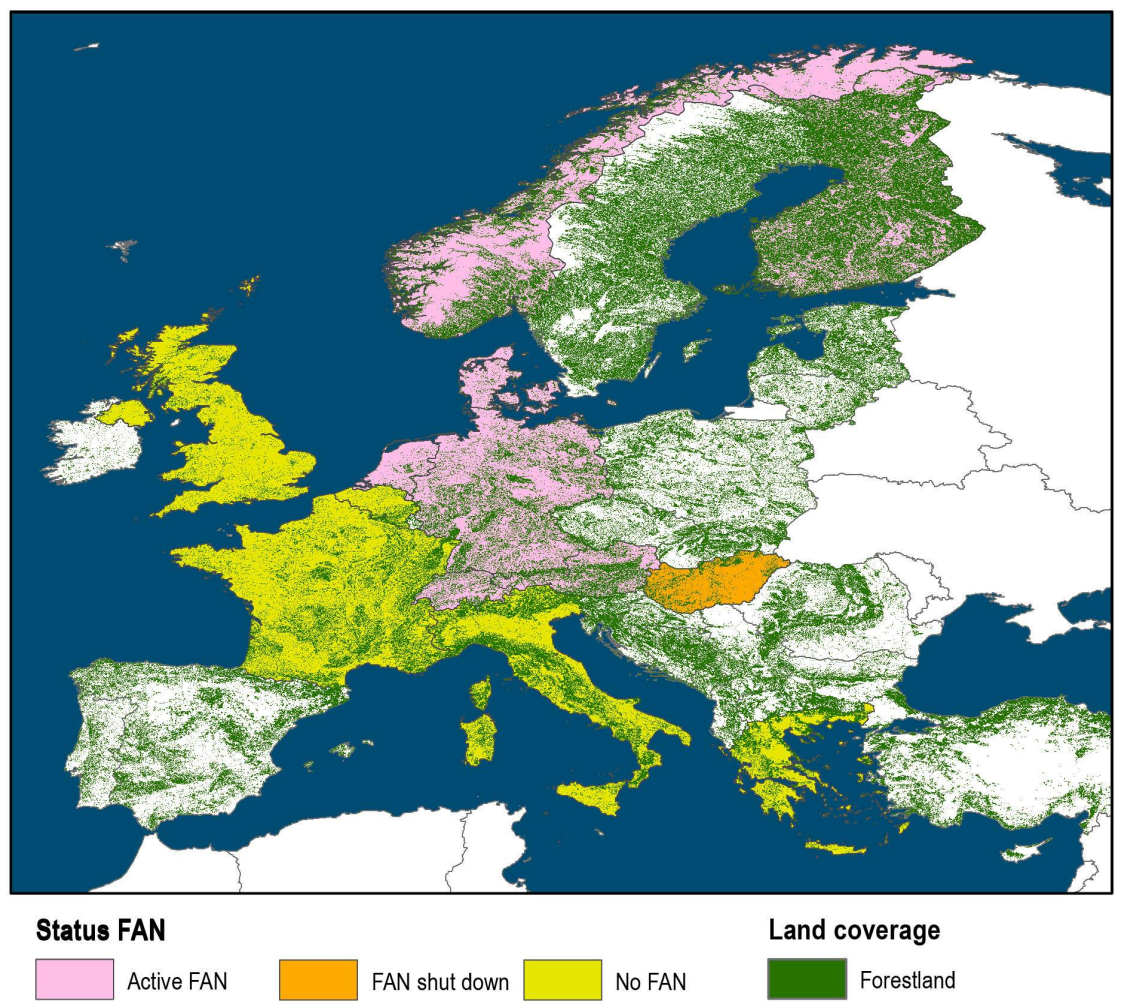

Figure 2. Matching information on forestland cover and the status of Forest Accountancy Data Networks (FANs). Forestland cover as classified by the European Environment Agency (EEA) forest land classification [27].

\subsection{Units of Survey and Reporting}

The unit of investigation in an FAN is typically a forest holding. Several cut offs determine whether an enterprise may belong to a certain FAN. The following considerations are crucial for interpretations and conclusions of FAN results. The possible types of ownership of forest land are manifold. Forest might be owned by private physical persons, legal entities, enterprises, churches, communities or states. Another consideration is the definition of a forest enterprise. Is a connection between a forest and a farm mandatory or does any kind of forest ownership constitute a forest enterprise in terms of an FAN? An according limitation can systematically exclude a bunch of possible forest owners such as new forest owners $[5,28]$ or industrial forest owners. Definitions of the sample might also include limitations according to the economic output. The example of the Austrian FAN for small-scale forestry shows in detail an unapparent limitation of the standard output ( $\mathrm{SO} \ldots$ average monetary value of the total output at farm-gate prices [29]). As monitored forest enterprises in this specific FAN are a subsample of the farms observed by the Austrian FADN, therefore they share the SO restrictions of the FADN [30]. A further common constraint is the size limit of the forest land. Within the DACH-region, the minimum forest land for enterprises belonging to the national accountancy network for (large) forest enterprises ranges from 50 ha $(\mathrm{CH})$, to 200 ha (D) and 500 ha (A) [10]. The management objective of a forest enterprise is commonly supposed to be profitability-oriented timber production. Nevertheless, deviating management objectives such as amenity, recreation, protection, nature conservation, and hunting may exist. Defining the key management objective of an enterprise is mandatory for the interpretation of interfirm comparisons [3,31]. The sampling scheme influences whether representative national results can be computed. Representativeness of sampled farms in a statistical sense is hard to create for an FAN as it depends on the goals and frame conditions. Usually random sampling, quota sampling, purposive sampling, systematic sampling, cluster sampling, or a combination of those techniques are used [3]. 
Even in the DACH-region, the underlying sampling schemes vary strongly. In the Austrian FAN for larger enterprises, the sample develops as driven by the interest of the enterprises. The national German FAN is oriented on calculated quotas for the federal states. The federal states use different sampling techniques (e.g., Baden-Württemberg uses purposive sampling [12]) to select individual enterprises. The Swiss FAN uses an approach which was seen as representative in the beginning [12] but developed towards a quota sample affected by self-selection, comparable to the national German FAN [10]. Circumstances hampering real representativeness of FAN results are self-selection bias based on the principle of voluntariness, motivation for participation (e.g., higher economic interest) and continued participation (e.g., panel effects [32]) [33]. Anyhow, in the Austrian FAN for larger enterprises, socio-economic data of about $30 \%$ of forest holdings $>500$ ha and $50 \%$ of forest land in this category is collected [34], which leads to a high relevance of the computed results.

In principle, it seems appropriate to avoid major modifications of the research design as they can trigger inconsistent time series. "Frequent changes, in data collection, data analysis and in supervising staff have a clearly negative impact" [19] (p. 39). However, changes in frame conditions may necessitate adaptations and there is always a potential for fruitful amendments of existing frameworks as documented by several studies for Germany [35-37], Austria [13,34,38,39] and Switzerland [40,41]. E.g., the consistency of results from the national German FAN were influenced by the reunification of Germany in 1990 as well by implementing the recommendations of the German Forestry Council (DFWR [42]) in 2003 [15]. In Austria, the upper size limit of forest area in the FAN for small-scale forestry was recently extended from 200 ha to 500 ha, thereby conceptually closing the statistical gap between the two Austrian FANs [18]. In the Swiss FAN, major conceptual improvements necessitated modifications regarding the assignment of costs and revenues. This resulted into inconsistent data sets before and after the fiscal year 2008 [25]. The latest revision of the Swiss forestry statistics brought a new definition of forest enterprises, and consequently the population of enterprises dropped from 1469 to 713 units. This was acknowledged by the reduction of the FAN's sample size from 200 to 160 elements [43].

\subsection{General Concepts of Accounting and Economic Ratios for Timber Production}

Quite naturally, the major source of data for any accountancy network is the companies' book-keeping. In practice, this may be either obligatory, financial accounting or any voluntary book-keeping e.g., in terms of managerial accounting. It is a crucial characteristic, what type of economic documentation is underlying the results of any specific FAN. The possibilities range from the exclusive recording of cashflows resulting from transactions to sophisticated concepts of cost accounting including or even focusing on imputed figures for items, which are not even recognized by financial accounting. Typically, financial accounting has to comply with tax regulations, does not recognize cost centers and is hardly suited for assessing the efficiency of operations. Therefore, most FANs have adopted some scheme of managerial accounting, where inputs are differentiated according to type of cost and cost centers and their valuation is at least potentially independent from tax regulations [44]. For imputed items such as unpaid family labor, respective physical quantities like working hours have to be recorded and are processed together with unit values. In case the information requirements address ratios of different levels of economic documentation simultaneously, it is possible to adapt the framework of data collection accordingly. For instance, in the Austrian network of larger forest enterprises, specific items like profit according to financial accounting are recorded in addition to the managerial figures, whereas some ratios such as cashflow are explicitly defined in terms of surrogates [45].

While FANs of the DACH-region have in common that they document accounting data in terms of costs and revenues, the specific details and rules for the collection of monetary information vary to a considerable extent. The German FAN follows the recommendations of the DFWR by applying the so-called 'forest product plan' [42]. Consequently, all costs and revenues of an accounting period are mandatorily allocated to one of the 23 product groups that are summarized in 5 product areas 
(production of timber and other goods; nature protection and restoration; recreation and environmental education; services for third parties; and tasks of public authority and other official functions) [19]. For example, product area 1 encompasses timber, non-wood goods, leasing as well as hunting and fishing. A concept of direct costing is applied at the level of product groups, whereas overheads are adjoined to the product areas only. Hence, profitability of timber production cannot be assessed specifically. The focus of the Austrian FAN for larger enterprises is the delimitation of costs and revenues occurring with timber production alone [45]. In principle, this FAN as well as the Swiss one follows a concept of full cost accounting where respective shares of overheads are allocated to the individual branches of the forest enterprise [15]. Whereas in Germany and Austria salaries are generally pooled in the cost center administration, in Switzerland the operational activities of rangers are recorded specifically and adjoined to the respective cost centers.

The common form of documentation is a master balance sheet for the respective core business. Selling on the stump being rather the exception than the rule in the DACH-region, harvesting dominates the cost structure of timber production and accounts for roughly half of the input. On average for the fiscal years 2008-2013, administrative costs took a share on total costs of 35\% (D-private), 28\% (A) and 22\% (CH-timber production) whereas silvicultural costs amounted to $17 \%$ (D-private), $8 \%$ (A) and 13\% (CH-timber production) respectively [10].

Although monetary information dominates among the data collected, additional non-monetary information is required as well. Whereas some variables are documented for grouping similar enterprises (e.g., region of production), others may be important for the interpretation of the monetary results or even targets of the investigation themselves. According to the MOSEFA guidelines [3], three main categories of non-monetary information can be distinguished: (i) Quantities of input and output in physical terms can be targets in themselves or supplementary to the monetary information; (ii) Quantitative measures describing the forest resource are often of interest for statistical analyses and (post)stratification; and (iii) Qualitative information may include items such as the education of the forest owner, geographical context or management goals. Table 2 provides five examples for each of these categories and indicates their recognition in the national German FAN, the Austrian FAN of larger enterprises and the Swiss FAN.

Table 2. Non-monetary information documented in the national German FAN (D), Austrian FAN for larger enterprises (A) and the Swiss FAN $(\mathrm{CH})$ according to the respective guidelines for data collection $[45,46]$ (5 examples for each of the categories).

\begin{tabular}{ccccc}
\hline Category & Item of Non-Monetary Information & \multicolumn{3}{c}{ Country } \\
\hline & D & A & CH \\
\hline I-Quantities of input and output & & & \\
\hline Blue collar working hours & $\sqrt{ }$ & $\sqrt{ }$ & $\sqrt{ }$ \\
Number of planted seedlings & & $\sqrt{ }$ & $\sqrt{ }$ \\
Mutput & & & $\sqrt{ }$ \\
& Annual cut & $\sqrt{ }$ & $\sqrt{ }$ & $\sqrt{ }$ \\
Afforested area & $\sqrt{ }$ & $\sqrt{ }$ & $\sqrt{ }$ \\
\hline II-Quantitative measures describing the forest resource & & & \\
\hline Area of hunting ground & $\sqrt{ }$ & $\sqrt{ }$ & \\
& Age structure of the growing stock & $\sqrt{ }$ & & \\
Standing volume & $\sqrt{ }$ & & $\sqrt{ }$ \\
Length of forest road network & $\sqrt{ }$ & $\sqrt{ }$ & $\sqrt{ }$ \\
Area requiring cable yarding & & $\sqrt{ }$ & $\sqrt{ }$ \\
\hline III-Qualitative information & & & \\
\hline Type of ownership & $\sqrt{ }$ & & $\sqrt{ }$ \\
Region of production & & $\sqrt{ }$ & $\sqrt{ }$ \\
Silvicultural system & $\sqrt{ }$ & & $\sqrt{ }$ \\
Management goal & & $\sqrt{ }$ & $\sqrt{ }$ \\
Type of management & & $\sqrt{ }$ & \\
\hline
\end{tabular}


The definitions and rules for the collection of specific items in the three FANs are quite heterogeneous. Thus, the direct comparison of figures from different networks might even be misleading. Although all of the three FANs comprise for example information about the allowable annual cut or the productive forest area, international comparison presumes the harmonization of these ratios [12]. The combination of monetary and non-monetary information enables various calculations such as imputing average costs of management activities, calculation of income per working hour or cost unit period accounting [3]. Respective figures can be deviated in all the three mentioned FANs but are not comprehensively included in standard reporting [15].

In the German FAN for small-scale forests in the state of Baden-Württemberg, highly detailed information of the farms regarding the inventory is documented. For each enterprise, information about the tree species and age classes is recorded. Participants in this network receive forest management plans for free every 10 years. This measure is intended as an incentive for participation on the one hand and provides valuable and standardized information about standing volume, increment, and annual allowable cut to the FAN on the other [33,47].

\subsection{Sustainability}

At least in Central Europe, forestry has for centuries been very strongly associated with the term sustainability. Since the idea of sustainable forestry was presented by von Carlowitz [48] in 1713 , the common understanding developed and is nowadays much wider than in its origins. Whereas in the beginnings sustainability meant a constant amount of annual cut, the definition was enriched with aspects such as assortments, timber quality, revenues, finally also social and ecology aspects. Operational definitions for sustainable timber production at enterprise level might thus be not consistent, neither within a single network nor at the international level. The easiest way for monitoring sustainability in FANs is to account the annual cut and compare it with the allowable annual cut. This ratio, the so-called rate of utilization, shows if the amount of harvested timber is sustainable in terms of quantities. It can, if not already implemented as key figure, be calculated for all FANs of the DACH-region $[25,45,49]$. The meaning of this result can be refined with more detailed information about the annual cut and the allowable cut (e.g., separation of intermediate and final yield or tree species). One step further goes an approach in the Austrian FAN for larger enterprises. Using a model calculation, the hypothetical profit referring to a felling volume corresponding with the annual allowable cut is calculated $[18,50]$. Based on the assumption of fixed stumpage value per $\mathrm{m}^{3}$ of harvest, sustainability of harvesting can be assessed by comparing the real results with the hypothetical ones from the model. Differences indicate the impact of over- or undercutting on profitability on the one hand and the asset value of the growing stock on the other [18]. However, respective results must be interpreted prudently as the actual structure of fellings in terms of tree species, assortments, timber quality, and harvesting costs may differ significantly from the sustainable one. Where a specific and reliable figure of allowable cut is not available, as is often the case in small farm forests, a regionally defined measure for sustainable production as derived from the national forest inventory can be used for addressing this issue at least at aggregate levels [51].

Altogether, evaluation of sustainability should always be based on long-term observations, as results from single years might be affected by special conditions (e.g., calamities, timber prices, and other factors). The long-lasting orientation and the annual investigation make FANs valuable research structures for this purpose.

\subsection{Multifunctionality, Diversification and Total Economy of Farm}

Depending on the size of the forest land, the type of forest owner, management goals, and many other possible factors, the significance of a forest enterprise to the owner's income situation varies strongly. Whereas the expectation might be that smaller holdings usually have lower significance for the owner than larger ones, some examples prove this wrong. In the unfavorable production conditions of mountainous regions, forestry may produce a substantial part of a farm's income [7]. 
On the other hand, a large forest enterprise might under the aspect of diversification [52] be just one part of its owner's portfolio and in some cases even with other management goals than profit maximization. Managers need adequate information for establishing objectives and to compare the actual performance with these objectives. An example of the Austrian FAN for small-scale forestry shows how to assess the income from forestry based on the data recorded in the national FADN using some model calculations [30]. Using this approach, the significance of the forestry branch of combined farm-forestry enterprises can be estimated, which subsequently can be used for establishing and evaluating objectives at farm level.

FAN may serve to investigate multifunctionality as far as economic activities of forest enterprises are concerned and respective monetary inputs and/or outputs accrue. At least in principle also, opportunity cost such as revenue forgone due to tradeoffs could be addressed. Conversely, welfare of stakeholders associated with the multiple use of forests in terms of external effects cannot be assessed on the basis of accounting data and are hence no core issue of FANs. On the other hand, the scope of an FAN may exceed the notion of multifunctional forestry as also activities which are not related to the forest may be documented in order to grasp the total economy of the unit of investigation.

Timber production is for most forestry enterprises the core business, but typically not the only field of activity. Several enterprises enhance their business portfolios with auxiliary activities (AA) like several forms of recreation and tourism, services for third parties, and consulting (to name just a few). The opportunities for diversification vary considerably between enterprises, depending on their ecological, economic and social conditions [52]. National laws may regulate the type (e.g., prerequisites required by trade laws) and range (e.g., in Austria some activities are accepted as minor forestry activities as long as they do not exceed a specific amount of turnover) of certain activities. A relevant issue in this context is the question of property rights. Whereas for example in Germany and Austria where the hunting right is directly related to land ownership, such a linkage does not exist in most parts of Switzerland. Thus, hunting is a mandatory AA in German and Austrian FAN (at least documented revenues from leasing) while the Swiss FAN comprises no information about this branch [10]. The extent to which AAs are recorded defines the potential for assessing the degree of diversification of forest enterprises. For the DACH-region, the capability of the documentation was recently investigated [15]. In the national German FAN, all operational activities are assigned to one out of 23 product groups. In case an activity is performed under the heading of a separate legal entity, it should not be documented as an AA. A subdivision of AAs into sub-cost centers is not feasible [15]. In the Austrian FAN for small-scale forestry, no other AAs beside timber production are recorded, as in most cases forestry itself is a branch of the farm. In the FAN for larger enterprises ( $>500$ ha), the only obligatorily documented AA is hunting. According to the guidelines of the FAN [45], any other AA may be registered optionally, according to the individual demands. However, in many cases it's ultimately up to the field agent collecting the data whether certain costs or revenues which do not belong to timber production are simply omitted, recorded as neutral or adjoined to a specific AA. Delimitation is linked neither to the legal form nor to the volume of the respective activity. The database system provides the technical preconditions for a differentiation of AAs into sub-cost centers. Since 1997, 11 predefined cost centers may be addressed for documenting AAs. Another 7 cost centers are available for any kind of further, company-specific AA. On average (1997-2011), each company shows 5.7 AAs [15], which indicates a quite high degree of diversification [52]. The approach of the Swiss FAN differs from the ones used in Germany and Austria. The biggest difference regards the meaning of cost centers and cost units. Forest management is differentiated into four so-called cost units as dependent from the respective primary management goal: besides commercial forestry which is devoted to timber production, protection, recreation as well as nature conservation and landscape management are distinguished. Further AAs are assigned either to the main cost unit 'material goods' or to 'services' [15]. A crucial question for the interpretation of results is, at what level overheads are assigned to different lines of production of activity. E.g., timber production and hunting are 
considered jointly in Germany, whereas the Austrian framework applies full cost accounting for each of these activities.

\section{Discussion}

The stated aim of this paper was to give an overview of and evaluate the research method 'forest accountancy data network' with special consideration of sustainable multiple use forestry. Systematic literature search lead to a body of 19 relevant publications dealing with FANs. However, much information on this topic is documented in gray literature such as conference proceedings and project reports only or not generally accessible at all. At least some of this material has been identified via the analysis of references and is documented in terms of supplementary material to this review paper (see Table S1). Links to information on existing FANs and their results are provided as well (see Table S2).

Accountancy networks are a very specific although not widely applied concept for empirical economic research and especially suited for monitoring purposes. The polypolistic structure of the timber markets and high equity ratios of forest enterprises imply a specifically low level of competition among producers at least in Europe. This is a most valuable basis for voluntarily providing accountancy data and hence for the implementation of such research infrastructure.

At least for the time being, there is definitely no scope for a harmonized international monitoring scheme in analogy to the FADN, the EU having no common forestry policy. Also in future, neither a legal obligation for EU member states nor international activities based on gentlemen's agreement are considered likely. However, growing concern about rural development and the livelihood of farms may well suggest national extensions of the FADN in regard to forestry, as is to some extent the case in Austria. Conversely, only very specific information requirements can justify the significant costs of purely forestry accountancy data networks so that hardly any new FANs will be established. Anyhow, the legal regulations underlying the FADN are a most valuable reference, that such monitoring data must not be used for taxation purposes. The typical framework for data collection follows the structure of a master balance sheet where the inputs are differentiated simultaneously according to the type of cost and cost centers. The level of economic documentation may range from cash flows and financial accounting standards up to cost accounting comprising also imputed elements. Most significant ratios like the contribution margin (timber proceeds net of harvesting costs), turnover per capita, and unit costs (e.g., $€$ per ha of artificial regeneration) can be derived when combining monetary and non-monetary information. Apart from repeatingly providing statistical data for monitoring purposes, FANs serve as a most valuable empirical source of detailed data e.g., for establishing typologies of forest enterprises [53-55] and economic modelling [30,36,56].

Although some FANs have already a long tradition as monitoring instruments, they are by no means necessarily static structures. Conversely, quite frequent innovations can be observed due to adaptations and amendments in response to upcoming requirements or frame conditions. Thus, the investigative frontiers of this research approach are continuously pushed forward. In regard to sustainability, indications for physical sustainability in terms of overall timber volume and monetary sustainability by means of simplistic model calculations referring to the level of allowable cut have been implemented so far. However, there is potential for more sophisticated approaches in relation to timber production e.g., by a further differentiation according to tree species, assortments, grades and harvesting conditions [57]. A further extension towards ecological and social aspects of sustainability may be considered as well, although respective information is hardly readily available in a standardized form at enterprise level and would most likely require specific records to be implemented. Respective examples in the social sphere could be the number of employees, the number of working accidents or investment in training and education. Examples for ecological indicators are the shares of natural regeneration, broadleaves planted or selective cutting.

Conceptionally, the economics of timber production is at the core of respective monitoring approaches. Other lines of production up to the total economy of the holding may be captured as 
well, thereby more or less comprehensively documenting the degree of diversification and respective developments. The economics of multiple use forestry may thus be addressed as well, as far as specific production takes place and respective inputs and outputs enter the accounts. On top of that, there is at least the theoretical potential to extend the investigation towards opportunity costs, revenues foregone, and economic trade-offs associated with the multiple use of forests [57].

Implementation and running of accountancy networks is rather costly and requires safeguarding respective financial means for a longer period of time. However, specific figures are hardly available with the newly established network in Brandenburg being an exception. There, the estimated initial costs amounted to some $€ 616,000$ (corresponding to about $€ 2280$ per unit of investigation) [37] and the current costs for the fiscal year 2016 were reported in the magnitude of $€ 118,000$ (or $€ 645$ per unit). The German Federal Ministry of Food and Agriculture awards some $€ 300$ to the data-collecting institutions for each documented enterprise [19]. At least part of this money is passed on to the participating enterprises for providing their data. Confidential information from other networks indicates that current financial requirements are at least at that level but may well exceed $1000 €$ annually per unit of investigation. In many cases, the total costs are considerably higher than specific cashflows due to substantial in-kind contributions of the involved institutions.

Supplementary Materials: The following are available online at http://www.mdpi.com/1999-4907/9/4/220/s1, Table S1: Sources found and selection process of the systematical literature review. Titles in brackets [] contain the original translation of the title and indicate the availability of at least an English abstract. PS ... Primary search result; EP ... Excluded records from primary search; SS ... Secondary search result; ES ... Excluded records from secondary search; FA ... Full-text articles assessed for eligibility; IQ ... Publications included in the qualitative synthesis; CI ... Citation, Table S2: Identified European FAN including additional information about the operator and or links to recent publications of results.

Acknowledgments: We gratefully acknowledge the most valuable information which has been confidentially provided by a number of experts in this field. Supported by BOKU Vienna Open Access Publishing Fund.

Author Contributions: Philipp Toscani (P.T.) and Walter Sekot (W.S.) conceived the concept of this review paper. The systematical literature review as well as the expert interviews were performed by P.T. Setting up the structure, analyzing the results and writing the manuscript were done conjointly by P.T. and W.S. Graphics and tables were mainly designed by P.T., as well as the finalization and submission of the manuscript.

Conflicts of Interest: The authors declare no conflicts of interest. As there are no funding sponsors they had no role in the design of the study; in the collection, analyses, or interpretation of data; in the writing of the manuscript; and in the decision to publish the results.

\section{References}

1. Eurostat Forests, Forestry and Logging-Statistics Explained. Available online: http:/ / ec.europa.eu/eurostat/ statistics-explained/index.php/Forests,_forestry_and_logging (accessed on 18 January 2018).

2. Food and Agriculture Organization (FAO). FRA 2015-Terms and Definitions-Forest Resources Assessment Working Paper 180; FAO: Rome, Italy, 2012.

3. European Forest Institute. Guidelines for Establishing Farm Forestry Accountancy Networks: MOSEFA; Niskanen, A., Sekot, W., Eds.; European Forest Institute Research Report; Brill: Leiden, The Netherlands; Boston, MA, USA; Köln, Germany, 2001; ISBN 90-04-12289-3.

4. Schmithüsen, F.; Hirsch, F. Private Forest Ownership in Europe; Geneva Timber and Forest Study Paper 26; Economic Commission for Europe: Geneva, Switzerland, 2010.

5. Weiss, G.; Hogl, K.; Rametsteiner, E.; Sekot, W. Privatwald in Österreich-neu entdeckt [Private forest property in Austria-newly discovered]. Schweiz. Z. Forstwes. 2007, 158, 293-301. [CrossRef]

6. Hyttinen, P.; Kallio, T.; Olischläger, T.; Sekot, W.; Winterbourne, J. Monitoring Forestry Costs and Revenues in Selected European Countries; EFI Research Report No. 7; European Forest Institute (EFI): Joensuu, Finland, 1997; Volume 7, p. 83.

7. Toscani, P.; Sekot, W. Assessing the Economic Situation of Small-Scale Farm Forestry in Mountain Regions: A Case Study in Austria. Mt. Res. Dev. 2017, 37, 271-280. [CrossRef] 
8. Council of the European Union. Council Regulation (EC) No 1217/2009 of 30 November 2009 Setting up a Network for the Collection of Accountancy Data on the Incomes and Business Operation of Agricultural Holdings in the European Community; European Union: Brussels, Belgium, 2009; Volume 1217/2009, p. 12.

9. Niskanen, A.; Hyttinen, P. (Eds.) Prospects of International Statistics on Farm Forestry; EFI Proceedings; European Forest Institute: Joensuu, Finland, 1999; ISBN 952-9844-70-0.

10. Bürgi, P.; Sekot, W.; Ermisch, N.; Pauli, B.; Möhring, B.; Toscani, P. Forstbetrieblicher Kennzahlenvergleich Deutschland-Österreich-Schweiz. Schweiz. Z. Forstwes. 2016, 167, 73-81. [CrossRef]

11. Jöbstl, H.A. Kosten und Leistungsrechnung in Forstbetrieben. Eine Anleitung für die Betriebsabrechnung mit dem EDV-Programmpaket der Universität für Bodenkultur mit einer einführenden Grundlegung; 1 Auflage; Österreichischer Agrarverlag: Wien, Austria, 1981.

12. Sekot, W.; Fillbrandt, T.; Zesiger, A. Improving the International Compatibility of Accountancy Data: The 'DACH-Initiative'. Small-Scale For. 2011, 10, 255-269. [CrossRef]

13. Toscani, P. Methodische Aspekte und Informationspotentiale Forstlicher Testbetriebsnetze in Österreich; University of Natural Resources and Life Sciences, Vienna: Vienna, Austria, 2016.

14. Brabänder, H.D. Zehn Jahre Betriebsvergleich im Privatwald von Westfalen-Lippe. Allgemeine Forstzeitschrift 1980, 35, 145-148.

15. Toscani, P.; Sekot, W.; Ungerböck, E. Die Erfassung der Bereitstellung von Nicht-Holzprodukten und Dienstleistungen in den Testbetriebsnetzen der DACH-Region. Austrian J. For. Sci. 2015, 132, 103-130.

16. Moher, D.; Liberati, A.; Tetzlaff, J.; Altman, D.G.; Group, T.P. Preferred Reporting Items for Systematic Reviews and Meta-Analyses: The PRISMA Statement. PLoS Med. 2009, 6, e1000097. [CrossRef] [PubMed]

17. Hyttinen, P.; Kallio, T. (Eds.) Cost Accountancy in European Farm Forest Enterprises; EFI Proceedings; European Forest Institute: Joensuu, Finland, 1998.

18. Sekot, W. Forest Accountancy Data Networks as a Means for Investigating Small-Scale Forestry: A European Perspective. Small-Scale For. 2017, 16, 435-449. [CrossRef]

19. Möhring, B.; Wilhelm, S.; Dög, M. The Relevance of Economic Data from Forest Accountancy Networks for Forest Management, Research and Politics Consultation. Small-Scale For. 2018, 17, 25-40. [CrossRef]

20. Bundesrepublik Deutschland. Gesetz zur Erhaltung des Waldes und zur Förderung der Forstwirtschaft (Bundeswaldgesetz); Bundesgesetzblatt: Bonn, Germany, 1975; BGBl. I S. 1037.

21. Sekot, W.; Toscani, P.; Karisch-Gierer, D. Bertiebsvergleiche im österreichischen Kleinwald. AFZ-Der Wald 2017, 23, 42-44.

22. Von Blomberg, M.; Volckens, F.; Möhring, B. Ergebnisse aus dem BB-Forstbetriebsvergleich 2016. AFZ-Der Wald 2017, 23, 26-30.

23. Stridsberg, E.; Algvere, K.V. Cost Studies in European Forestry; Studia forestalia Suecica; Skogshögskolan: Stockholm, Sweden, 1967.

24. Bundesministerium für Ernährung und Landwirtschaft. Die Wirtschaftliche Lage der Forstwirtschaftlichen Betriebe-Buchführungsergebnisse des Forstwirtschaftsjahres 2016; Bundesministerium für Ernährung und Landwirtschaft: Bonn, Germany, 2018.

25. Bürgi, P.; Thomas, M.; Pauli, B. Forstwirtschaftliches Testbetriebsnetz der Schweiz: Ergebnisse der Jahre 2011-2013; Bundesamt für Statistik: Bern, Switzerland, 2015.

26. BMLFUW Nachhaltige Waldwirtschaft in Österreich-Datensammlung zum Österreichischen Wald. Stand: Februar 2015. 2015. Available online: https://www.bmnt.gv.at/forst/oesterreich-wald/waldzustand/ datensammlung2017.html (accessed on 18 January 2018).

27. European Environment Agency Forest Type 2012-Copernicus Land Monitoring Service. Available online: https://land.copernicus.eu/pan-european/high-resolution-layers/forests/forest-type (accessed on 2 February 2018).

28. Hogl, K.; Pregernig, M.; Weiss, G. What is new about new forest owners? A typology of private forest ownership in Austria. Small-Scale For. 2005, 4, 325-342. [CrossRef]

29. Eurostat Eurostat-Statistics. Explained-Glossary: Standard output (SO) 2018. Available online: http: / / ec.europa.eu/eurostat/statistics-explained/index.php/Glossary:Standard_output_(SO) (accessed on 18 January 2018).

30. Toscani, P.; Sekot, W. Assessing the Economy of Small Scale Farm Forestry at The National Scale: The Case of Austria. Small-Scale For. 2015, 14, 255-272. [CrossRef] 
31. Von der Wense, W.-H. Der Betriebsvergleich in der Forstwirtschaft; Georg-Augustin-Universität: Göttingen, Germany, 1990.

32. Sekot, W. Stichprobendynamik als methodisches Problem von Testbetriebsnetzen. In Wald-Besitz-Ökonomie2007; Fakultät für Forst- und Umweltwissenschaften der Universität Freiburg, Forstliche Forschungs- und Versuchsanstalt Baden-Württemberg, Eds.; Freiburger Forstliche Forschung-Berichte; Eigenverlag der FVA: Freiburg, Germany, 2007; Volume 74, pp. 41-52.

33. Brandl, H. Experiences in Collecting Data on Farm Forest Enterprises over More than Three Decades. Small-Scale For. 2011, 10, 135-147. [CrossRef]

34. Sekot, W. Interfirm Comparison and Benchmarking Exercises within the Framework of a Forest Accountancy Data Network. In The Multifunctional Role of Forests-Policies, Methods and Case Studies; Cesaro, L., Gatto, P., Pettenella, D., Eds.; EFI Proceedings; European Forest Institute (EFI): Joensuu, Finland, 2008; pp. 161-169.

35. Kroth, W.; Bartelheimer, P. Gutachten zur Verbesserung der methodischen Grundlagen des BML-Testbetriebsnetzes Forstwirtschaft; Im Eigenverlag: Bonn, Germany, 1981.

36. Dieter, M. Nutzung von Testbetriebsnetzdaten für gesamtwirtschaftliche Rechnungssysteme. [Utilizing the data out of accountancy networks for national accounting]. In Berichte Freiburger Forstliche Forschung; Fakultät für Forst- und Umweltwissenschaften der Universität Freiburg und Forstliche Forschungs- und Versuchsanstalt Baden-Württemberg: Freiburg, Germany, 2007; pp. 75-82.

37. Spinner, K.; Thode, H.; Setzer, F. Abschlussbericht zum Projekt "Entwicklung eines Konzeptes für ein Testbetriebsnetz der Forstwirtschaftlichen Zusammenschlüsse und des Kleinprivatwaldes im Land Brandenburg; Landesforstanstalt Eberswalde: Potsdam, Germany, 2006; p. 72.

38. Sekot, W. Forstliche Testbetriebsnetze; Im Eigenverlag: Wien, Austria, 1990.

39. Bürg, J.; Sekot, W. Methodenprobleme und Entwicklungsperspektiven Forstlicher Testbetriebsnetze in Österreich; Schriftenreihe des Instituts für Sozioökonomik der Forst- und Holzwirtschaft; Im Eigenverlag: Wien, Austria, 1997; Volume 29.

40. Seiler, A.; Glanzmann, G.; Boissonnas, G.; Echsle, A. Projekt FIS Schlussbericht-Aufbau eines Forstökonomischen Informationssystems Erfordert umfassende Anstrengungen; ETH Zürich, Lehrstuhl für Betriebswirtschaft: Zürich, Switzerland, 1992; p. 65.

41. Nagel, P.; Hercher, W.; Hartebrodt, C. Typologisierung des forstwirtschaftlichen Testbetriebsnetzes der Schweiz. Schweiz. Z. Forstwes. 2013, 164, 158-164. [CrossRef]

42. Deutscher Forstwirtschafts Rat. DFWR-Empfehlungen 1998: Transparenz und Vergleichbarkeit der Ergebnisse von Forstbetrieben. AFZ-Der Wald 1999, 54, 414-416.

43. Swiss Federal Office for the Environment BAFU (Ed.) Jahrbuch Wald und Holz 2016; Umwelt-Zustand; Bundesamt für Umwelt: Bern, Switzerland, 2016.

44. Penttinen, M.; Hakkarainen, J. Ratio Analysis Recommendations for Non-Industrial Private Forest Owners; Niemikorpi, A., Ed.; Proceedings of the University of Vaasa; University of Vaasa: Vaasa, Finland, 1998; ISBN 951-683-763-8.

45. Sekot, W.; Rothleitner, G. Kennzahlenanalyse und Kennzahlenvergleich auf Basis der Forstlichen Betriebsabrechnung; Österreichischer Forstverein: Wien, Austria, 2009.

46. Bundesministerium für Ernährung, Landwirtschaft und Verbraucherschutz. Buchführung der Testbetriebe (Forstwirtschaft)-Ausführungsanweisung zum Erhebungsbogen für Forstbetriebe; Bundesministerium für Ernährung und Landwirtschaft: Bonn, Germany, 2012; p. 43.

47. Brandl, H.; Hercher, W.; Löbell, E.; Nain, W.; Olischläger, T.; Wicht-Lückge, G. 20 Jahre Testbetriebsnetz Kleinprivatwald in Baden-Württemberg; Forstwissenschaftliche Fakultät der Universität Freiburg und Forstliche Versuchs- und Forschungsanstalt, Ed.; Berichte Freiburger Forstliche Forschung; Eigenverlag der FVA, Freiburg: Freiburg, Germany, 1999.

48. Von Carlowitz, H.C. Sylvicultura Oeconomica-Hausswirthliche Nachricht und Naturmäßige Anweisung zur Wilden Baum-Zucht; Huss, J., von Gadow, F., Eds.; Faksimile der Erstauflage Leipzig 1713.; Kessel: Remagen-Oberwinter, Germany, 2012; ISBN 978-3-941300-56-9.

49. Bundesministerium für Ernährung und Landwirtschaft (BMEL). Buchführung der Testbetriebe-Buchführung der Testbetriebe Grundlagen zur BMEL-Testbetriebsbuchführung; Bundesministerium für Ernährung und Landwirtschaft: Bonn, Germany, 2015; p. 170. 
50. Sekot, W. Kleinwaldforschung mit Hilfe von Testbetriebsnetzen-eine europäische Perspektive? In Erklärungsmuster im Flickenteppich-Ein Kaleidoskopischer Einblick in die Privatwaldforschung im Jahr 2012; Freiburger Forstliche Forschung-Berichte; Eigenverlag der FVA: Freiburg, Germany, 2012; pp. 87-101.

51. Sekot, W. Nachhaltigkeitsbeurteilung im österreichischen Kleinwald auf Basis von Regionalhiebsätzen. Cent. Gesamte Forstwes. 2011, 128, 195-218.

52. Ungerböck, E.; Sekot, W.; Toscani, P. Looking beyond timber: Empirical evidence for the diversification of forest enterprises and the profitability of auxiliary activities in Austria. For. Policy Econ. 2015, 18-25. [CrossRef]

53. Selter, A.; Hartebrodt, C.; Brandl, H.; Herbohn, J. A critical comparison of typologies of small-scale forestry in Baden-Württemberg derived using single and multiple criteria. Small-Scale For. 2009, 8, 25-42. [CrossRef]

54. Bormann, K. Classification of forest enterprises. In International Workshop on Figures for Forests-Proceedings; Fakultät für Forst- und Umweltwissenschaften der Universität Freiburg, Forstliche Versuchs- und Forschungsanstalt Baden-Württemberg, Eds.; Berichte Freiburger Forstliche Forschung; Eigenverlag der FVA: Freiburg, Germany, 2010; pp. 1-8.

55. Selter, A. Der Einsatz Multivariater Statistischer Methoden zur Erarbeitung einer Betriebstypologie für den Bäuerlichen Privatwald; Albert-Ludwigs-Universität: Freiburg im Breisgau, Germany, 2006.

56. Statistisches Bundesamt, Wiesbaden Umweltnutzung und Wirtschaft-Bericht zu den umweltökonomischen Gesamtrechnungen 2014. Available online: https://www.destatis.de/DE/Publikationen/Thematisch/ UmweltoekonomischeGesamtrechnungen/Querschnitt/UmweltnutzungundWirtschaftBericht.html (accessed on 28 February 2018).

57. Jöbstl, H.A. Kosten-und Leistungsrechnung in Forstbetrieben-Betriebsabrechnung für die Praxis; Schriften aus dem Institut für Sozioökonomik der Forst- und Holzwirtschaft; Kommsionsverlag Österreichischer Agrarverlag: Wien, Austria, 2000; ISBN 37040 1328-5.

(C) 2018 by the authors. Licensee MDPI, Basel, Switzerland. This article is an open access article distributed under the terms and conditions of the Creative Commons Attribution (CC BY) license (http://creativecommons.org/licenses/by/4.0/). 